\title{
The Justice and the Colombia Peace Talks
}

\author{
Ángel Emilio Muñoz Cardona \\ Professor of the Superior School in Public Administration of Antioquia, Medellin, Colombia \\ Email: angel@esap.gov.co
}

Received 4 March 2016; accepted 4 July 2016; published 7 July 2016

Copyright (C) 2016 by author and Scientific Research Publishing Inc.

This work is licensed under the Creative Commons Attribution International License (CC BY).

http://creativecommons.org/licenses/by/4.0/

c. (i) Open Access

\begin{abstract}
The purpose of this research paper is to feed the reflection elicited by the peace talks in Colombia for that serve the construction a better country and a better society of the post-conflict to start from citizens' confidence in its institutions of justice. To achieve this, it is necessary to begin by the concepts of justice that makes Adam Smith in "Lessons of Jurisprudence" and is associated with the concept of utilitarianism of John Stuart Mill as search for the general happiness. The investigation goes to do traceability exhaustive of the Peace Accords in Colombia to compare them with those achieved by other societies of the post-conflict in two countries in Europe and one from Latin America. A historical and theoretical count, that allows us to conclude in the need for a peace agreement to Colombia based in the justice, in other words, respectful of the rights of victims and territories affected by the armed conflict. An agreement for the peace that prohibits at the demobilized is political representatives by popular voting, as show of support at the victims. Punishment of citizen value over those who committed heinous crimes against humanity.
\end{abstract}

\section{Keywords}

Utilitarianism, Transitional Justice, Sympathy, Social Forgiveness and Social Justice

\section{Introduction}

"We are a very ferocious animal, we are a terrible animal we the humans, either here in Europe, in Africa, in Latin America wherever. Our violence is extreme. Our history is a history of war, is a never-ending story. But, we are the salt of the Earth”. Sebastião Salgado. Documentary film "Salt of the Earth" (2014).

If the axiom is accepted "Justice is the fundamental pillar on which the whole social edifice is supported" (Smith, 1997, p. 186). And yes we understand justice as the way to avoid resentful answer, and not as a way to prevent recidivism or to exemplify, (Smith, 1995); so what are the social costs of peace in Colombia if the demobilized combatants come to form political parties without payment of compensation to victims? Colombia peace talks between 1991 and 2016 left many without flavors with the public policies: “forgive and forget" and 
"transitional justice" on legal punishments for crimes against humanity; since they equaled the social forgiveness with the legal forgiveness ${ }^{1}$ through public betting for the peace: Forgive and Forget and Transitional Justice on legal punishments for crimes against humanity; since they equaled the social forgiveness with the legal forgiveness1 through public betting for the peace: Forgive and Forget and Transitional Justice. ${ }^{2}$

The $14,4 \%$ of the Colombians that are victims of the armed conflict live in very remote areas of large cities; for being a minority, they are forced, politically and socially to accept such agreements of justice without compensatory punishment in order to achieve peace that benefiting at $85.6 \%$ of the Colombians. How to understand the peace and social utility in Colombia if left 7,000,000 victims without the right to compensation justice? Hence, the main objective of the investigation is to show the importance of justice in the construction of a new post-conflict society; a society in which the right of victims is above the political benefit of the armed actors.

After noting what successes and failures of the peace talks in Ireland, Spain and El Salvador, the investigation concluded in the necessity, for well of democratic institutions not accept that the demobilized can be: selectmen, councilors, deputies, congressmen, mayors, governors, ambassadors and presidents or can form new electoral political parties. Thus, it is preserved in Colombian society national confidence in the institutions of justice.

Research is bibliographical because it is based on theoretical discussions of political philosophy of utilitarianism. It is historic because it is based on the analysis of the agreements reached between the government and guerrilla groups.

The essay has been divided into four parts. In the first part, it makes a count of the peace talks in Colombia made from 1991 through 2016. In the second part, it working the theoretical concepts of sympathy and justice as engines for the social building construction. Principles defined by the economists and philosophers Adam Smith and John Stuart Mill. In the third part, a comparison between it utilitarian and the utilitarianism on the peace talks in Spain, Ireland, El Salvador and Colombia is made. In the fourth part are provides the conclusions.

Before starting, we go to give a brief socio economic characterization of Colombia in the last year according to World Bank reports and the National Administrative Department of Statistics (DANE). According to economic indicators from the World Bank (2015), Colombia has a gross domestic product of 377.7 billion dollars and a growth at constant prices of the $3.2 \%$ for 2015 . Colombia has 1,102 municipalities, of which $60 \%$ are rural with a population of $30.4 \%$ of the national total $(48,228,000)$. The agricultural sector contributes $6.1 \%$ to GDP and $16.3 \%$ of employment (DANE, 2015). 6.17\% of the municipalities (68) have a robust development. $64.6 \%$ of municipalities (712) have intermediate levels of development (DANE, 2015). 29\% of municipalities (320) have an incipient development (DANE, 2015), the vast majority of the poorest municipalities have been victims of the armed conflict.

\section{The Beginning of the Colombia Peace Talks}

International events such as the European economic integration, the fall of the Berlin Wall and perestroika in the late 80s served of initiative to the peace talks in Colombia, were even a big boost in Colombian society for the approval of the constitutional reform in 1991 (Bakke \& Peters, 2011: p. 4; Guáqueta, 2007: p. 426). Between 1989 and 1994 five of seven existing guerrilla groups were demobilize, only the Revolutionary Armed Forces of Colombia (FARC) and National Liberation Army (ELN), did not demobilize (Guáqueta, 2007). In 1999 the National Government resumes peace talks within an area of distention of 42,000 square kilometers; process that ended with the strengthening of armed groups in number of combatants and financial resources through illicit activities such as drug trafficking and kidnapping.

From 2002 to 2010 the national government returned at the distention zone and made front the guerrilla, counteracted criminal actions as of drug trafficking and kidnapping, the national army caused great losses at the guerrilla ranks. Between 2003 and 2006 were immobilized 20 groups paramilitary and 31,671 fighters. ${ }^{3}$ In 2008

\footnotetext{
${ }^{1}$ Equality for legal impunity which is not approved by international law for crimes against humanity. Even, neither by the domestic laws of the countries by attempted murder. Consider, for example, the case of Turkish Ali Agca who on May 13, 1981 did shoot on the life of political and religious leader Juan Pablo II. Although the Pope visited his attacker in prison and forgave him, the offender was sentenced to 29 years in prison in Italy and Turkey for attempted murder and murder of a journalist.

${ }^{2}$ The International Center for Transitional Justice defines transitional justice as a response to systematic violence or widespread at human rights. Its aim is to meet the victims and promote peace initiatives, reconciliation and democracy. Transitional justice is justice adapted to societies that are transformed after a long period of violation of human rights. For the Colombian case are 52 years, from 1964 to 2016, a conflict that has left more than 6,500,000 victims. Repair programs consist of a combination of material and symbolic benefits to victims, which can range from financial compensation to requests for official pardon.

${ }^{3}$ Official file of the Presidential High Council for Reintegration. "4 years transforming the lives of thousands of Colombians" http://www.reintegracion.gov.co/Es/proceso_ddr/Paginas/proceso_paz.aspx
} 
old members of immobilized paramilitaries groups created new emerging criminal gangs that function in 17 departments and 152 municipalities and they financed with extortion, kidnapping, drugs trafficking to small and large scale. ${ }^{4}$ In 2012 the National Government searched again resume the peace talks, however she is shown difficult to achieve. First, the high social decay that affects more than a third of Colombian municipalities, mainly miners, hydroelectric, oil production and banana exporters, as is deduced the research report on the armed conflict and the economic success of companies of (Camacho \& Rodriguez, 2013). Second, the high political decomposition that has permeated public administration and democracy: corruption political, Narco-Politics, Para-politics and filtration for guerrillas in the field of government administration, as says (Chaparro, 2002: p. 109). Third, the loss of credibility in the institutions of justice.

It is not possible that democratic actions as the popular vote serves of political initiatives to forgive crimes against humanity, says (Guáqueta, 2007: p. 425). The public policies "Forgive and Forget and Transitional Justice" cannot undermine justice. The justice institutions cannot lose their moral function of give and administer justice. The politician forgiveness cannot be equal to social forgiveness, as he says (Herrera, 2005: p. 85-87). The political benefits at corrupt politicians, lack of research, and punishment to military personnel accused of crimes against humanity and lack of transparency in the administration of justice in Colombia hinder the real achievement of the peace (Human Rights Watch, 21/12/2015). ${ }^{5}$

Peace in Colombia is possible: First, if justice is constructed as a fundamental principle for the existence of new post-conflict society, as stated by the Scott Adam Smith. Second, if the post-conflict society retrieves the public values: accountability, transparency, solidarity, responsibility, responsiveness and gender equality as say John Mill and Harriet Taylor Mill: "It cannot build a just and prosperous society if she only works with the 50\% of its population and not with 100\%” (Mill \& Taylor Mill, 2001: p. 239, 252). Public values that are crucial to the preservation and promotion of democracy and good governance, as stated by (Beck \& Bozeman 2007; Bevir 2010; Skelcher, Mathur, \& Smith, 2005).

\subsection{Relevant Agreements of the Colombia Peace Talks from 2012}

The August 26, 2012 the Government of Colombia and the Revolutionary Armed Forces of Colombia, FARC, they signed the "General agreement on the termination of the conflict and building a stable and lasting peace". November 19, 2012 the peace talks began in Havana, Cuba.

The May 26, 2013, without the participation of the victims, that are mostly farmers, Government and FARC achieved the first agreement on agricultural issues, called: "Towards a new Colombian countryside: an integral rural reform". Agreement, which seeks to provide sufficient land to peasant families with land shortages, plans on housing, drinking water, technical assistance, training, education, adaptation of land, infrastructure and land reclamation (COLPRENSA, 26/05/2013). But how much does it cost to recover the Colombian countryside? That is, make it profitable for the farmer and his family; in other words, that the products can be competitive in international markets. How much does provide basic government services to all agricultural zones forgotten? In order to reverse the political and social damage to municipal administrative structures, that for more than 30 years have generated the illegal agricultural economics (Ospina, 2/13/2016).

The June 13, 2013 the FARC make it clear that the peace process does not mean a formal surrender of weapons, because he is not defeated nor are disunited. The peace talks are a political agreement of wills for abandoning hostilities rather than domination.

The August 28, 2013 approving the Legal Framework for Peace (Legislative Act 01, 2012). The Agreement is examined by the Constitutional Court on July 25 and approved in the Congress in June 2012, but, is claimed by

\footnotetext{
${ }^{4}$ See webpage of newspaper El Tiempo. http://www.eltiempo.com/archivo/documento/CMS-8931640 and see too http://www.usofficeoncolombia.org/understanding_colombia/pdf/para_politics.pdf

${ }^{5}$ Human Rights Watch in different mass media claim: "The agreement justice is an impunity agreement"

http://www.eltiempo.com/mundo/ee-uu-y-canada/proceso-de-paz-hrw-critica-acuerdo-de-justicia-del-proceso-de-paz-en-cuba/16464887

"The peace agreement in Colombia is a mass of empty promises"

http://internacional.elpais.com/internacional/2015/12/22/colombia/1450811785 717837.html "Dispute between Colombia and Human Rights on the peace process” http://www.elmundo.es/internacional/2016/01/08/568f122ee2704eec7b8b45ed.html “Colombia: FARC accordance with impunity facilitates "false positives" https://www.hrw.org/es/americas/colombia "Human Rights Watch criticized the endorsement of the Framework for Peace” http://www.noticiasrcn.com/nacional-pais/human-rights-watch-critico-el-aval-al-marco-paz "HRW criticizes Special Jurisdiction Agreement for Peace” http://caracol.com.co/radio/2015/09/24/internacional/1443055342_992878.html and on March 28, 2016 "HRW denounces impunity for military by” false positives http://www.elcolombiano.com/colombia/paz-y-derechos-humanos/hrw-denuncia-impunidad-para-militares-por-falsos-positivos-LX381973
} 
Human Rights Watch. José Miguel Vivanco, noted that the articulated "opens the door to impunity forguerrillas, paramilitaries and soldiers responsible for atrocities". The main reason is because crimes against humanity can be classified as crimes of an exclusively political character, if the government give political status to the FARC. Similarly, they are the same guerrillas who have developed their own laws of payment in prison. The law allows benefits to demobilized equal to the average citizen in order; such as, access to elected office and being appointed as public servants (Legislative Act 01, 2012).

On November 6 of 2013 it reach the second agreement in the agenda of the peace talks between the FARC and the Government on the political participation of the guerrilla with full guarantees. In this agreement, can be read that there is no restriction of any kind to the participation of demobilized in politics, provided they confess their crimes and implore social forgiveness; offenses such as: drug trafficking, kidnapping, extortion, attacks on civilians with car bombs, planting of anti-personnel mines and damage to public infrastructure. Demobilized persons may participate in political contests and be governors or mayors elected while they are serving their sentences (Legislative Act 01, 2012).

On December 3, 2013 the President of Colombia to the OAS calls flexibility for crimes under international human rights violation, Human Rights in the context of armed conflict. Requests the application of Transitional Justice "It's not about sacrificing justice for peace, but that justice cannot become an obstacle in the process" (Human Colombia, 2009-2016; Archive of the President of the Republic 22/01/2014). ${ }^{6}$

The May 16, 2014 the third agreement on illicit crops and drug is achieved. Agreement rotating on three basic points: crop substitution program, drug prevention and solution to the phenomenon of production and marketing. In this agreement, can be read as part of transitional justice: no jail for the guerrillas, the non-extradition and amnesty for drug trafficking; since the traffic of drugs was used by guerrillas to finance political war, not the personal enrichment of the guerrilla leaders.

The May 12, 2015the State Council in Colombia says FARC are not a terrorist group. They are a recognized armed group, and therefore, in consistent with International Humanitarian Law, IHL, cannot be categorized as a terrorist group (Human Colombia, 2015). ${ }^{7}$

The June 4, 2015 it is established an agreement for the creation of the Truth Commission, on October 18, 2015, according Joint Communique \# 62, it starts with the first humanitarian measures of search, location, identification and dignified return of the remains of missing persons. Second, the creation of a Special Unit for the Search of Persons Kidnapped or Disappeared in the context and by reason of armed conflict. ${ }^{8}$

On 29 November 2015 the chief negotiator of the Colombian Government sets out the principles for achieving and maintaining peace, which are: 1 . The end of the armed conflict by political, not military solution, which is long and painful. 2. Present and future victims are the ethical reason of the peace talks. 3 . The definition of justice is not limited to punitive punishment. There are forms of restorative justice that contribute to a wider satisfaction of the rights of victims. 4. The reparation to the 7,000,000 of victims in 52 years of armed conflict is essential. Symbolic, spiritual and also material. 5. Forgiveness is a personal decision, but society cannot remain in rancor, hence the decision peace is incumbent on all Colombians. 6. Broad political participation. 7. Financing agreements requires the contribution of all, which at the same time is an incentive for international cooperation (Human Colombia, 2015).

On December 15, 2015Agreementon Victims is achieved. According criticized by Human Rights Watch, for the Special Court for Peace will implement a sanctions regime that do not reflect accepted international standards on the appropriate punishment in serious abuses against humanity and make it practically impossible, for Colombia to comply with its binding obligations accordance with international law to ensure justice for crimes against humanity and war crimes (Human Rights Watch, 21/12/2015). ${ }^{9}$

On March 9 of 2016 the Congress of Colombia agrees reforming the Law 4th, 1991 on Public Order. The

\footnotetext{
${ }^{6}$ Affirmation on justice which can also be read at the intervention of the Colombian President in the talks "Dividends of Peace" in Madrid. Speech recorded by the Press in January 2014. Website:

http://wsp.presidencia.gov.co/Prensa/2014/Enero/Paginas/20140122_08-Palabras-Intervencion-Presidente-Colombia-Juan-Manuel-Santos-te rtulia-Los-dividendos-de-la-paz.aspx

${ }^{7}$ The January 29, 2015 start peace talks with the National Army of Liberation, ELN. The benefits achieved by the FARC also benefits to guerrillas of the ELN.

${ }^{8}$ Recorded by Radio Caracol report “Government and FARC reach agreement on missing”. See website http://caracol.com.co/radio/2015/10/18/nacional/1445137053 778422.html

${ }^{9}$ The Special Court for Peace punishes grave breaches of international humanitarian law committed by the FARC, ELN and government agents. In they are included the 3000 victims of the "false positives". The "False positives" are innocent peasants that were killed by the army (in combat alleged) accusing them of guerrillas.
} 
agreement empowers the President for the creation of zones of concentration the demobilized combatants within the framework agreement on transitional justice. The reform includes: 1 . Location areas of the demobilized are temporary. 2. No demobilized combatants in areas where there are illicit crops and illegal mining are located. 3. They are not located in border areas or urban areas of large cities. 4 . The weapons will be destroyed with international verification (Newspaper El Tiempo 09/03/2016). ${ }^{10}$

On April 9, 2016 Government and guerrilla groups seek to find legal formulas to making constitutional the peace agreements reached and final surrender of weapons. For that agreements on convictions imposed on crimes against humanity they cannot be modified by other governments.

Finally, on June 23, 2016 the National Government and the FARC guerrillas signed peace agreement, this represents an end to war. The National Government set up 23 rural areas extinction, which serve as areas of preparation for the life civil the guerrilla and delivery of weapons. The deadline for total surrender of weapons by the FARC and the beginning of the organization as a political party is six months.

To do constitutional peace agreements, Government and guerrilla are based on Articles 3, 6 and 10 of the Geneva Agreement, which allows the parties to define the internal sanctions as long as the armed conflicts don't have affected other countries (the Geneva Conventions, 1949: pp. 37-40). But how can crimes against humanity such as: drug trafficking, kidnapping and anti-personnel mines not affect other countries directly or indirectly? International agreements of commercial benefit as ATPDEA, international aid for mine clearance of anti-personnel mines, arms trafficking, migration, refugees, political exiles, remittances, transfers and drug trafficking affect other countries' economies. The kidnappings with extortion purposes or political interchanges, carried out by guerrillas have affected the human dignity of thousand people-national and foreigners-, but especially the universal value of human life, as enshrined in Articles 5 to 9 of the Rome Statute of the International Criminal Court International (2002: pp. 4-9).

\subsection{Declaration of the Principles of Victims}

To give effect to the rights of victims, as the basis of justice, the National Government and the FARC created the Integrated System of truth, justice, reparation and non-repetition; which aims to: the satisfaction of the rights of victims, clarifying the truth, accountability, legal security, the non-repetition, coexistence and reconciliation (Agreement on the victims of the conflict, 15/12/2015: p. 6).

The Integrated System of Truth, Justice, Reparation and Non-Repetition shall be composed of five mechanisms or measures: Commission to clarify the truth, coexistence and non-repetition. Institution that seeks to know the truth, clarify the violations of International Humanitarian Law and promoting coexistence. The Special Unit for finding persons reported missing. Its purpose is finding and identifying all missing persons. The Special Court for Peace. Includes the Room Amnesty and Clemency and Peace Court. Charged with administering justice, prosecute and punish serious violations of human rights and IHL. Reparation-measures for building peace. Satisfy, indemnify and restore the rights of victims. Make collective reparation of territories, populations and human communities affected. Guarantees of non-repetition. Compliance agreements by the end of the armed conflict (Agreement on the victims of the conflict, 15/12/2015: p. 7).

The members of the Commission to clarify the Truth, Coexistence and Non-Repetition will consist of 11 persons nominated by the community and victims' organizations; and will be selected by nine members of the National Government and the guerrillas (Agreement on the victims of the conflict, 15/12/2015: p. 15). ${ }^{11}$

The Declaration of principles of victims provides that are not subject to amnesty or pardon crimes against humanity, the genocide, serious war crimes, hostage-taking or other severe deprivation of liberty, the torture, extrajudicial executions, enforced disappearances, the violent carnal access and other forms of sexual violence, child abduction, forced displacement, in addition to the recruitment of children as stipulated in the Rome Statute (Agreement on the victims of the conflict, 15/12/2015: Article 40, p. 28; Rome Statute, 2002: pp. 5-6). Such acts of violation at the international humanitarian law during the conflict armed by the guerrilla leaders and the state, will be punished between 5 to 8 years maximum, if they are recognized by the accused and implores the social

\footnotetext{
${ }^{10}$ The guerrilla responds: "The Law of reform to Public Order that approved the Congress of the Republic are open-air prisons, are not areas for transit but camps of concentration. What we are proposing are transit areas where historically we have coexisted with communities, are areas to implement and promote development”. Taken from

http://www.vanguardia.com/colombia/350873-las-farc-cuestionaron-zonas-de-concentracion Published by COLPRENSA, Medellin on 16/03/2016.

${ }^{11}$ The delegation of the 9 members who will choose the commissioners not is known distribution of them, how many government and how many of the guerrillas. As little, is established the profession or level of know ledges. Only requires that they be persons of recognized ethical soundness, knowing armed conflict, human rights and IHL.
} 
forgiveness. $^{12}$

The Special Jurisdiction for Peace will establish to leaders symbolic sanctions or remedial on the right of the victims, they will have a minimum duration of fulfillment of remedial and restorative functions of five and a maximum of eight years. ${ }^{13}$ They will understand effective restrictions of freedoms and rights; such as, of residence and movement, necessary for its fulfillment (Agreement on the victims of the conflict, 15/12/2015: p. 39).

The remedial and restorative functions, are social projects of development that the demobilized going to do together with the community. Planning and execution of social development projects that serve to improve the quality of life of the victims of the conflict in specific territories; the demobilized can move to the region, with the approval of the Special Court for Peace, and participate with community leaders in the implementation of the Development Plan with a Territorial Approach for Peace (Agreement on the victims of the conflict, 15/12/2015: pp. 39-40). ${ }^{14}$

The demobilized subordinates who participated in serious crimes against humanity under orders imposed by his superiors, they must do remedial and restorative functions between two and five years (Agreement on the victims of the conflict, 15/12/2015: p. 39). ${ }^{15}$

The armed actors who participated and not recognize their guilts and did not ask forgiveness social; they will have effective imprisonment for not less than 15 years nor more than 20 years in the case of very serious behaviors (Agreement on the victims of the conflict, 15/12/2015: p. 39).

The active participation of demobilized in the Development Plan with a Territorial Approach for peace it is a strategy that facilitates the restoration of the social tissue, rapprochement between offenders and community, it facilitates the compensation of crime electoral and political rapprochement of the demobilized leaders. In other words, it facilitates the future integration of former combatants into the political life of the regions as mayors, governors, councilors, deputies, congressmen and presidents.

\section{Sympathy and Justice Axioms of General Happiness}

With the nomination at the Nobel Peace Prize in the 2015, of boss Timoshenko guerrilla, in the city of Stockholm, it is validating at international level in a certain way, guerrilla action. The international community accept or do not know the plight that living families of more than 2700 kidnapped, many of them with over 10 years ago in captivity, as says Maria Clara (Ospina, 20/05/2015, 23/12/2015). ${ }^{16}$ Which invites to ask us, from classical utilitarianism, by what is it socially good, what is it correct?

The use of kidnapping as a form of enrichment or midst of political justification or a bargaining tool for the exchange of prisoners; should not be supported by no country on earth, or empathy for anyone citizen of the world or by anyone international institution as a fighting mechanism valid; because we affects everyone in the value of human beings; because man becomes a thing or an object. So, what is universal benevolence? What is utilitarianism or social usefulness in general? Like they question themselves (Mill, 2002: p. 22; Hauser, 2008: pp. 18-19, 138-140).

John Stuart Mill defines the utilitarianism as the search for the general happiness and defines the utilitarian as

\footnotetext{
${ }^{12}$ Sanctions to agents of the State, will be decided before the signing of the Final Peace Agreement, respecting what is already established in the Special Justice for Peace regarding own sanctions, alternatives and ordinary (Agreement on the victims of the conflict, 15/12/2015: p. 39).

${ }^{13}$ Note that the agreement speaks of repair functions and restorative to victims, not punitive sanctions. This implies that the demobilized enjoys some freedom of movement and different treatment to an offender.

${ }^{14}$ The guerrillas commits to remedial and restorative functions: reconstruction works infrastructure in areas affected by the conflict, participation in the programs of cleaning and decontamination of the territories of antipersonnel mines, unexploded ordnance or explosive remnants of war. Programs of illicit crop substitution, contribution to the search, location, identification and recovery of remains of people killed or reported missing in the context and during the conflict and participation in programs of repairing the environmental damage, such as reforestation (Agreement on the victims of the conflict, 15/12/2015: p. 51).

${ }^{15}$ It is noteworthy, that in the Agreement on the Victims no sanctions are specified for those who breach repairing and restoring functions; as little, are established fulfillment conditions, which leaves open the possibility of they can continue to enjoy the benefits of jurisdiction even non-compliance with the conditions imposed by the Special Court for Peace.

${ }^{16}$ Maria Clara Ospina, columnist for the newspaper El Colombiano of 20 May 2015 asks: Where are the more than 2700 hostages of the FARC that have not yet been returned? Where are they! What became of them? Why not talk about this issue in peace talks in Havana, Cuba It seems to the negotiators, both of the government as of the FARC, have to intention that us to forget of them. http://www.elcolombiano.com/donde-estan-los-secuestrados-CN1953206
} 
the exclusive pursuit of the private gain (Troyer, 2003: pp. xxiv-vi). ${ }^{17}$

For Mill, the happiness that enjoying a society is product of human conquests, it is the result of human capacities for self-government and self-determination in public life. It is not the result of the utilitarian political actions of a governing, as Bentham thought, but rather, of the self-realizations of society, of the capacity for self-government of each citizen for well of all others, as says (Muñoz Cardona, 2010: p.47).

Achieving to increase the social usefulness depends of the sympathy feelings, says Smith, "of the citizen perception of a situation. Of the reasons that they have for unite wills and work together for well of all and each one. When it perceiving a situation, we put ourselves in the place of another, and we share with him your pleasure or pain. Approving the result of a passion, if it is considered appropriate to its purpose, that is to say, equivalent to sympathize with that" (Smith, 1978: p. 3).

In other words, it approves or disapproves an action, not by the person, but for what he did or did not do. While this approach is plausible and socially accepted as a criterion of justice, it can get to be, in certain special cases, as an inhumanity; such is the case, for example; the guerrilla or rapist of minors who have committed crimes against humanity and he is sentenced to spend the rest of his life in prison. But if after a year of imprisonment becomes to the gospel, showing true transformation of repentance and invokes the social piety, asking for a new opportunity in the name of God. It seems unfair not to forgive it, give him a new opportunity.

In situations like this, Smith says emphatically, that the legal order must not back down and must carry out the uttered judgment, either by the sympathy due to at the victims that lost their relative and they demand justice or because the justice system cannot show weakness of character; since will serve others as a strategy to save of the sentence handed down and therefore, open the door, to more heinous crimes. A further losses on the credibility of justice, as they say (Smith, 1997: pp. 292-293; Hauser, 2008: pp. 19, 141).

The Colombian public policies to achieve peace: "Forgive and Forget" and "Transitional Justice", have pardoned heinous crimes against humanity; which benefits perpetrators but no at the victims. Facts that undermine the credibility since 1991 on justice and crumbling the social order in Colombia, as he says (Muñoz Cardona, 2014: p. 182).

If the sympathy is born of the perception of a situation, as it suggested Smith, so that, the individuals into a society are forced to make since their ethics, an objective analysis of the situation observed or perceived for them. Objective judgments where are contemplated mitigating and/or aggravating factors; which makes it possible the right decision to act for the benefit of all social, or as says Marc Hauser an ethics not natural but evolutionary, an ethics that evolves with the social history of man (Hauser, 2008: pp. 16-19).

Thence that for Smith, the utility of justice does not arise as a way to prevent recurrence or to exemplify, but rather as a way to avoid resentful response or the resentment, as they say (Smith, 1995; Hauser, 2008: pp. $140-143)^{18}$ and therefore social unrest. In this way, society as a whole protects itself from disintegration by not allowing the spread of injustice or anarchy produced by the unjust acts and tied to particular will.

But, why men tend to act in conformity with society and not exclusively according to their free will? By the sense of moderation, the sense of penalty or embarrassment. Man by nature seeks recognition and social acceptance, which motivates him to act avoiding the legal or moral sanction of himself, the other and the others (Alighieri, 2014: pp. 18-23; Smith 1997). Not is the religious ethics that shapes social behavior of man, are the feelings of reproach or embarrassment in front the threat of civil and civic sanction.

(...) no person shall complete, nor tolerably satisfied, for having removed from everything that would be reprehensible in his conduct, unless at the same time he has avoided blame or reproach of himself (Smith, 1997: p. 250). The prudent men avoid doing things that cause misfortune or schadenfreude, they do which is harmless to people (...). Do not you know that science more perfect, is the most sensitive at welfare and condition of the men? (Alighieri, 2014: p. 21, 43).

Not enough to save face in front of others, too is necessary doing it front to oneself; it is not enough to avoid embarrassment, but rather also is necessary not fall into feelings of guilt about the results. That is, society is the mirror that corroborates what is culturally accepted. Hence the importance it has for governments to combat the

\footnotetext{
${ }^{17}$ At the search of the general utility is known as utilitarianism. For the Utilitarianism an act is socially correct if it contributes to the increase in general happiness. The utility, thus is consequentialist; which means that is not intuitive. In other words, the utility is governed by the principle of cause and effect, subordinates the theory of behavior correct by the theory of general benefit. Therefore, utilitarianism seeks to maximize the general welfare. All ethical theory consists of two parts: a theory for social well, which are the products or services of most value for all society? And a theory of correct behavior, what should we do? (Mill, 2002: p. 22).

${ }^{18}$ Are used the notes on "Lessons of Jurisprudence" taken by a pupil in 1762, 1763 and 1766 on the course of Moral Philosophy and on "Lessons on Rhetoric" that Adam Smith taught at the University of Glasgow.
} 
social demoralization; preventing evil from grow and destroy the social order attained. That is the main object of the institutions of justice, as it claimed the English philosopher Francis Bacon in the Essays "Revenge is a kind of wild justice, such that the more it is inclined the human nature for do it, most necessary is the law for the remove it" (Hauser, 2008: p. 145).

That is why they do not exist civilized societies without justice. The unjust societies are barbaric and unacceptable, because they force the citizens to support with their own income the existence of corrupt, unfair and immoral governments (Hauser, 2008: p. 127).

To understand the social approach taken by Smith to justice, is necessary to understand the moral value of the compensation as foundation of peace and preservation of social order. For Smith justice does not depend on utilitarian political agreements, such as are the peace talks in Colombia but rather of due fulfillment of the rights of redress for victims. The plural recognition given by society as equal treatment. The impartial judge who dwells in every man, forces him, out of sympathy, to put oneself in the situation of the victim and understand your claim. The foundation of justice is in recognition of the damage done to the victim. That is to say, the appropriate sentence on the aggressor.

Resentment of victim, that incites to retaliate for the damage caused, is the real source of punishment for crimes. That which Grotius and others claim it is usually the original measure of punishment, that is to say, consideration of the public good, does not sufficiently explain the establishment of the punishments (Smith, 1996: pp. 5-7, 1995: pp. 137-138).

So to Smith the justice is not established by the utilitarian function that benefits a majority over a minority, but rather of the proper compensation of the victim. By the compensation due. Which means, strengthen the justice that benefits everyone in society, not permitting the disagreement, by unjust sentences or by violations to the just rights of victims. The civil and social order arises from the correct application of justice; as suggested by Kaplow and Shavell, "The idea that punishment should be proportionate to the seriousness of the offense is necessary if the aim of the justice system is to promote the welfare of individuals on an equal footing" (Kaplow \& Shavell, 2002: p. 328).

It is not about a justice based at "eye for eye", as Smith says "this is definitely a barbaric and inhumane practice, and it has been sidelined in most civilized nations" (Smith, 1995: pp. 139-140; Hauser, 2008: pp. 140-142). The origin of punishment is due more to a moral that one physical harm. It refers to resentment due to friends and family for their loss; the moral contempt done to the victim by a criminal. The emotions of suffering or sorrow, of grief and resentment, require more of the consolation of empathy and accompaniment; either demanding legal justice or from the simplest moral sanction, as: to ignore and despise the aggressor. Not is equaling the political and social rights of offenders with those of the integral citizens, as stated in the transitional justice in Colombia in the framework of peace talks (Agreement on the victims of the conflict, 15/12/2015).

Therefore, those behaviors that seek only utilitarian or personal gain, regardless of others, they are behaviors that deny the true nature of social being. In this way, for the public value of justice exists, all citizens should be treated equally before the law breaking, thus protecting the quality of life and good living in society. Must exist the good example. If the soldier and the guerrilla fighter have committed crimes against humanity, they must be equally punished.

If a political leader is accused of corruption, misappropriation of public funds for education and health, he must pay more jail than one who robs a bank. If the amount stolen gives ten years in prison, both must pay equal time into the prison, without favoritism. And if, by lack of in health resources, a citizen dies for does not have received adequate hospital care. The corrupt politician should be brought to justice for the crimes of: treason against public confidence, murder in second grade and robbery.

It is not possible that into the classification of the offense, some people are protected by the political favoritism and are convicted with great benefits of comfort, such as under house arrest. Others, for the contrary, do not have the same privileges. Such differences make of the politics a vice and not a virtue. They make of the justice an institution for the benefit of few ones and no for the good of the whole community

\section{Utilitarianism or the Utilitarian of the Peace Talks}

The peace talks in countries such as Spain, the United Kingdom and El Salvador show differences in the termination of the conflict, number of victims and duration of hostilities; which teaching us in how the cessation of hostilities was negotiated (Table 1). 
Table 1. Armed groups, number of victims and duration of the conflict.

\begin{tabular}{ccccc}
\hline Country & Armed Group & Victims & Conflict duration & Ideology \\
\hline Spain & ETA & 839 & 45 years & Nationalism \\
United Kingdom & IRA & 3.500 & 25 years & Identity \\
El Salvador & FMLN & 78.000 & 20 years & Politicians \\
Colombia & FARC & 7.000 .000 & 52 years & No clear \\
\hline
\end{tabular}

Table 1 shows the differences of the armed conflict in countries with equal or greater economic and social development to Colombia Research group: Government, Territory and Culture and the Center for Regional Economic Studies CEER of the ESAP.

1. Armed group ETA

ETA was a movement of armed nationalism that had by aims to defend the "right to decide of the Basque country", the right to the Basque opinion was respected by the French and Spanish states. Throughout the 45 years of armed conflict were caused 839 fatalities, of which 527 were civilians and were carried 84 kidnappings, as says (Fisas, 2010: p. 5).

The peace process is achieved with the support of a large majority of Basque citizens, Spanish and French who understand politics as a means of dialogue for consensus, defense and vindication of social and human rights. "Today Basque society advances in political rights and recognition capabilities to decide their future, o be consulted and their democratically expressed will is respected” (Fisas, 2010: pp. 9-15).

After 12 years of the end of armed conflict, the investigations to political organizations and culprits of crimes against humanity during the period of armed conflict they continue and are sanctioned by the Spanish government.

Facts of the peace process that increases the social confidence in its institutions of justice, avoid the resentful behavior of the population and social breakdown. In other words, utilitarianism or general happiness of Spanish society have grown.

\section{Armed group IRA}

Says Andres Cotrina that the Irish armed movement, IRA, was not religious but identity: the nationalists feel minority in Northern Ireland and the Unionists feel minority in the whole of Ireland, that is "double minority" (Cotrina Acosta, 2013: p. 2). Armed conflict by the Nationalist and Unionist identity that left 728 dead and 2772 injured in two and a half decades (Cotrina Acosta, 2013: p. 2, 6). The end of the conflict begins with the Downing Street Declaration of 1993; it proclaims the right of citizens of Northern Ireland to self-determination through referendum, if they do want be part or not from UK, as asserts (Cotrina Acosta, 2013: p. 5).

British and Irish society demanded the disarmament of paramilitary organizations with international verification. They require to the army and paramilitary renounce the use of force or threat to influence the outcome of the peace process; they just had to resort to exclusively democratic and peaceful means to change points of disagreement. The society condemns without exceptions all forms of violence-threats, beatings, and insults (Cotrina Acosta, 2013: p. 8). Meanwhile, the Irish government demanded the protection of human rights in accordance with established international agreements; since they form part of international law and should not be subject to bargaining in peace talks, as asserts (Cotrina Acosta, 2013: p. 9).

The importance of peace process realized in Ireland and Britain is the protection of the rights of the victims of the conflict. All citizens are equally protected and protected by law. Facts that have enabled Ireland to be one of the strongest economies in the European Union. That is, utilitarianism or the general happiness of the English and Irish society have grown.

\section{Armed Group FMLN}

The Farabundo Martí, FMLN, It was an armed movement that fought for the end of the dictatorship of the 70s and the restoration of political rights of Salvadoran citizens. During the 20 years of armed conflict were recorded 70,000 dead and 8,000 missing. The lack of fundamental freedoms, the repression and the socio-economic inequalities were the main trigger for war. The dialogues of peace begin with an agrarian and constitutional reform: in the legal field, military, electoral and human rights. Reforms that they put an end to the dictatorship of government as says (Fernández García, 2002: p. 7). ${ }^{19}$

${ }^{19}$ Of the 35 special powers that had the armed forces, only four functions are left for the protection of the national security (Salgar Antolinez, 15/8/2015). 
Although, Salvadoran society vote by the peace dialogues, were not able to demand at the negotiating staff, severe laws on crimes against humanity. Very probably because the Salvadoran army too was guilty. Similarly, Salvadoran society forgot to do monitoring to the peace accords signed.

The report of the Truth Commission was reduced to oblivion, because the peace pact resulted in total impunity. On the side of the guerrillas there were violations, but were neither $25 \%$ of those committed by the Salvadoran army. Peace pact approved by the Legislative Assembly in which was buried all possibility of justice.

The guerrilla group FMLN became a political group seeking of votes to win public elections and enjoy the benefits personal and political, of the electoral competition. Twenty years of struggle FMLN to transform the system of economic inequality and social in El Salvador was reduced to a simple electoral political participation, as says (Salgar Antolinez, 15/8/2015).

The Agreement of peace gave land at the demobilized peasants and USD 20,000 for work it but in the 2002 the agriculture of El Salvador collapse. Is consolidated an economic model for multinationals, the trade increased and increased the population of immigrants to the United States. Remittances are ranked first in the current account balance. El Salvador went from agro-export to be a country that lives mainly on remittances (El Salvador Reserve Central Bank, 2015). El Salvador has an economy of drug trafficking and money laundering that feeds the illegal economy of gangs and violence street, as they say (Salgar Antolinez, 15/8/2015; Coates \& Jiménez, 2009: p. 8, 9, pp. 21-28).

El Salvador peace talks teach that after of 24 years the new post-conflict society failed to restore the social fabric, for the marked absence of justice in peace processes. Justice institutions lost social credibility, what has plunged to the Salvadoran society in an economic backwardness and of distrust in the electoral politics even greater. Are not the different forms the illegal economy what really affect the economies of developing countries such as El Salvador and Colombia but the lack of transparency in the justice institutions.

In Colombia the peace agreements demonstrate the incapacity of Government for to impose on the rebels, facilitating injustice and impunity for crimes against humanity. Colombia peace talks are more a political gamble, that an authentic social commitment. That was demonstrated on 18 February 2016 when leaders of the negotiating table of the FARC in Cuba leave the Havana and enter the Guajira-Colombia, with more than 250 heavily armed guerrillas and were taken the local school for political proselytizing. The National Government verbally condemned this fact and called it a "challenge to the country's institutions". The Ombudsman called it rape at IHL because violated Article 13 of Protocol II of Geneva which governs non-international armed conflicts, the Article 13 confers special protection to the civilian population and its institutions (Semana Magazine, 03/15/ 2016).

Colombia peace talks not seek to improve the social distribution, but profit and consolidation of political machines. The peace talks has facilitated in the 2016 the foreign direct investment and sale of state enterprises in the electric sector and hydrocarbons; which worsening the economic welfare of all Colombians because they are missing assets the national companies, as she says (Ospina, 13/02/2016). In other words, Colombia peace talks in are more product of the search utilitarian of the political machines that of the search for the general welfare.

\section{Conclusion}

Demobilization and reintegration into civilian life of demobilized combatants have great economic cost and politic, but what really will cost is building a democratic society for peace. That is, the construction of a country without social exclusion; in other words, with better job opportunities, without political corruption, with an agro more diversified, modernized and competitive in the production of goods with export quality.

A country with more support for research, but above all, less clientelistic and corrupt, in such a way that violence does not continue through the conformation of new groups illegal with other modalities for illegality. Not the drug trade, or the micro-trafficking, neither political corruption, they are not the main source of social decay in Colombia but the absence of public values. In other words, they are the absence of reliable justice institutions and transparent. The problem of Colombia is a problem of social ethics more than of individual ethics.

Colombia has about 1500 criminal gangs that feed on the illegal economy, says (Ospina, 12/09/2015) and are strengthened with the weakness of justice, the political corruption and decomposition of the individual ethics; which translates in a high social decay in more than a $30 \%$ of Colombian municipalities, they are or have been victims of armed conflict directly or indirectly.

Colombia needs peace to improve the conditions and life expectancies of their nationals; but she also needs restore confidence in its policies institutions and of justice, for this is necessary, for respect to 7,000,000 of vic- 
tims, that the demobilized cannot participate as civil servants, representatives or public servants. That is, they cannot become: presidents or governors or mayors, senators, nor congressmen, nor deputies or councilors or aldermen and less representatives of social and communal organizations for all the crimes against humanity they committed.

Front at the apparent political and economic participation of demobilized combatants in regions affected by the armed conflict, as measure of restorative justice; it is necessary to teach communities how to formulate community development plans for the peace. How do oversight at the public resources of municipality or the locality; in such a way that the meager resources do not become private funds of political patronage and of the demobilized.

A society that knows their rights and duties to manage and enjoy of the public goods; that understands, in terms of Robert Owen, the need to work together in pursuit of the general good, is a society that reaches lofty ideals more easily that other societies, because of improving its distribution of wealth, as says (Stiglitz, 2002: p. 13), it is less puppet the selfishness of the market and is less prone to ideological fanaticism, such as: cultural or xenophobic, at clientelism political or religious, as says (Muñoz Cardona, 2015: p. 63, pp. 256-257).

They are societies of human beings with self-control and self-determination in front the deceptions and threats of political market of vote. For Milton Fisk, public goods are those goods that society needs to make viable their common projects of community; thus preserving the social order and justice. "Justice in a society aims to overcome conflicts in a way that common goods are provided, and therefore public resources that are required for it" (Fisk, 2004: p. 27).

This implies, form the society in public values; through social consensus of what is good because are appropriate for all, how to conciliate the interest public and private? How to sell the idea of common projects? As she questions (Reynaers, 2014: pp. 32-35). It cannot think justice and solidarity, that is in the social good, without first illustrate at the society in political consciousness, in recognition of the other as an equal, with the same fundamental rights of human person. In promoting public values, says (Reynaers, 2014: pp. 34-35).

The defense of the public assets and public resources, are the rational basis of the democratic elections, because they are the joint building and selection of better government plans. The government plans are the citizen base, for a welfare life and of quality for all. This is the reason whereby, the society supports with their vote at the committed political leaders in the execution of public works and legislation on public policies for general welfare, asserts (Muñoz Cardona, 2014, 2015: p. 257).

\section{References}

Agreement on the Victims of the Conflict (15/12/2015). Integral System of Truth, Justice, Reparation and Non-Repetition, Including the Special Court for Peace and Human Rights Commitment. Draft Joint: Government and Guerrillas.

http://equipopazgobierno.presidencia.gov.co/acuerdos/Documents/acuerdo-punto-victimas.pdf

Alighieri, D. (2014). The Divine Comedy. Madrid: Mestas Editions.

Archive of the Presidency of the Republic (1/22/2014). Dividends of Peace. Bogota: Press Room. Government Information System, GIS.

http://wsp.presidencia.gov.co/Prensa/2014/Enero/Paginas/20140122_08-Palabras-Intervencion-Presidente-Colombia-JuanManuel-Santos-tertulia-Los-dividendos-de-la-paz.aspx

Bakke, E., \& Peters, I. (2011). 20 Years Since the Fall of the Berlin Wall: Transitions, State Break-Up and Democratic Politics in Central Europe and Germany, United Kingdom. Cambridge: Intersentia Ltd.

Beck, J., \& Bozeman, B. (2007). Public Values: An Inventory. Administration \& Society, 39, 354-381. http://dx.doi.org/10.1177/0095399707300703

Bevir, M. (2010). Democratic Governance. Princeton, NJ: Princeton University. http://dx.doi.org/10.1515/9781400836857

Camacho, A., \& Rodriguez, C. (2013). Firm Exit and Armed Conflict in Colombia. Journal of Conflict Resolution: Sage, 57, 89-116. http://dx.doi.org/10.1177/0022002712464848

Chaparro, A. A. (2002). Political Culture and Forgiveness. Bogotá: Rosario Universitypress

Coates, K., \& Jiménez, F. (2009). Remittances Program. International Remittances in El Salvador. Mexico: Inter American Development Bank, Center for Monetary Studies, Multilateral Investment Fund.

COLPRENSA (5/26/2013). Statement on the Agreement of the First Point of the Peace Talks. Cali, Valle: Daily nes El País.com.co. http://www.elpais.com.co/elpais/judicial/noticias/lea-comunicado-sobre-acuerdo-primer-punto-dialogos-paz

Cotrina Acosta, A. (Compiler) (2013). Peace Processes: A Benchmark, Northern Ireland. Military University of New Gra- 
nada: Informational Series. UMNG-IEGAP \# 141. Institute of Geostrategic Studies and Political Affairs.

http://www.iegap-unimilitar.edu.co/images/docs/info141\%20procesos\%20de\%20paz.\%20un\%20referente\%20irlanda\%20 del\%20norte.pdf

DANE (2015). Great Integrated Household Survey (GIHS) 2014. Bogota: DANE.

El Salvador Reserve Central Bank (2015). Base of Economic and Financial Data. Monthly Income Family Remittances 1991-2016. El Salvador. http://www.bcr.gob.sv/bcrsite/?cdr=85

El Tiempo (09.03.2016). Unanimously Approved Reform of the Public Order Act. Bogotá, Colombia: Newspaper El Tiempo, Section Policy.

Fernández, G. J. (2002). Peace Process in El Salvador Ten Years Later by the Salvadoran Press. Research Group Current History-GEBC (PAI-HUM 315) University of Cadiz. II International Seminar Our Common Heritage, Cádiz (Spain), 22 April 25, 2002.

Fisas, V. (2010). Peace Process in the Basque Country. Barcelona: Escola de Cultura de Pau, Quaderns de Construcció de Pau, No. 16. http://escolapau.uab.es/img/qcp/procesos_paz_pais_vasco.pdf

Fisk, M. (2004). Public Goods and Radical Justice. A Political Morality for Partnership Resistance. Cali: University of Valle, Collection Arts and Humanities.

Guáqueta, A. (2007). The Way Back in: Reintegrating Illegal Armed Groups in Colombia Then and Now. London: Routledge.

Hauser, M. D. (2008). Moral Minds. How Nature Designed Our Universal Sense of Right and Wrong. Barcelona: Paidós.

Herrera, J. C. (2005). Reconciliation and Transitional Justice: Options Justice, Truth, Repair and Forgiveness (pp. 79-112). Political Paper No. 18, Bogotá.

Human Colombia (2009-2016). Chronology of Peace Talks. Bogota: Regional Centre for Human Rights and Gender Justice, Human Colombia. http://www.humanas.org.co/pagina.php?p_a=82

Human Rights Watch (21/12/2015). Analysis of the “Agreement on Victims of Conflict” Reached by the Government of Colombia and the FARC.

https://www.hrw.org/es/news/2015/12/21/analisis-de-human-rights-watch-sobre-el-acuerdo-sobre-las-victimas-del-conflict $\underline{0}$

Kaplow, L., \& Shavell, S. (2002). Fairness versus Welfare. Cambridge, MA: Harvard University Press.

Mill, S. J. (2002). Utilitarianism. Madrid: Alianza Editorial. Introduction, Translation and Notes of Esperanza Guisán Seijas.

Mill, S. J., \& Taylor Mill, H. (2001). Essays on Sexual Equality. Valencia: Cátedra, University of Valencia, Introduction of Neus Campillo.

Muñoz Cardona, Á. E. (2010). Introduction to Economics: A Social Vision and of Entrepreneurship. Medellin: Ude@, University of Antioquia, Engineering Faculty.

Muñoz Cardona, Á. E. (2014). The New Public Management in Sabaneta, Antioquia. Open Journal of Political Science, 4 , 180-194. http://www.scirp.org/journal/PaperInformation.aspx?PaperID=48453 http://dx.doi.org/10.4236/ojps.2014.43019

Muñoz Cardona, Á. E. (2015). Ethic of Citizen Responsibility: A Way for Peace. Medellin: Icolven, Research Work PostDoctoral, Vrije Univerisiteit Amsterdam, NUFFIC.

Ospina, M. C. (23/12/2015). Reasons to Celebrate This Christmas. Medellin: Newspaper El Colombiano, Opinion. http://www.elcolombiano.com/opinion/columnistas/motivos-para-celebrar-en-esta-navidad-BX3330726

Ospina, M. C. (20/05/2015). Where Are the Hostages? Medellin: Newspaper El Colombiano. http://www.elcolombiano.com/donde-estan-los-secuestrados-CN1953206

Ospina, W. (13/02/2016). The Resources of Peace. Bogota: Newspaper El Espectador, Special. http://www.elespectador.com/noticias/paz/los-recursos-de-paz-articulo-616416

Ospina, W. (12/9/2015). The War of Wars. Bogota: Newspaper El Espectador, Opinion. http://www.elespectador.com/opinion/guerra-de-guerras

Reynaers, A.-M. (2014). Public-Private Partnerships and Their Impact on Public Values. Netherlands: Drukkerij Grafic Image.

Rome Statute of the International Criminal Court (2002). Rome-Italy: General Secretariat of the United Nations. International Criminal Court. http://www.un.org/spanish/law/icc/statute/spanish/rome statute(s).pdf

Salgar Antolinez, D. (15/08/2015). Mistakes of El Salvador in Its Peace Accords. Bogota: Newspaper El Espectador.

Semana Magazine (3/15/2016). The Site Where “Walked” the Guerrillas in the Guajira. Bogota: El Tiempo, Section: Nation. http://www.semana.com/nacion/articulo/reunion-de-los-jefes-de-las-farc-fue-en-el-corregimiento-del-conejo-la-guajira/46 
$\underline{1080}$

Skelcher, C., Mathur, N., \& Smith, M. (2005). The Public Governance of Collaborative Spaces: Discourse, Design and Democracy. Public Administration, 83, 573-596. http://dx.doi.org/10.1111/j.0033-3298.2005.00463.x

Smith, A. (1997). Theory of the Moral Sentiments. Madrid: Alianza Editorial, Preliminary Study of Carlos Rodríguez Braun.

Smith, A. (1996). Lessons Jurisprudence. Madrid: National Printing the Official Gazette, Political Classics, Preliminary Study of Translation and Alfonso Ruiz Miguel.

Smith, A. (1995). Lessons in Jurisprudence. Granada: Library Comares of Legal Science Collection Argonauts, No. 1.

Smith, A. (1978). Theory of the Moral Sentiments. Mexico: Fondo de Cultura Economica, Introduction by Eduardo Nicol.

Stiglitz, J. E. (2002). The Economy of the Public Sector (3rd ed.). Barcelona: Antoni Bosch.

The Geneva Conventions (1949). Switzerland: International Committee of the Red Cross. https://www.icrc.org/spa/assets/files/publications/convenios-gva-esp-2012.pdf

Troyer, J. (2003). Classical Utilitarians. Bentham and Mill. United States of America Editions John Troyer.

World Bank (2015). World Development Indicators. Economy, Structure of Output. New York: World Bank. http://wdi.worldbank.org/table/4.2

\section{Submit or recommend next manuscript to SCIRP and we will provide best service for you:}

Accepting pre-submission inquiries through Email, Facebook, Linkedin, Twitter, etc A wide selection of journals (inclusive of 9 subjects, more than 200 journals)

Providing a 24-hour high-quality service

User-friendly online submission system

Fair and swift peer-review system

Efficient typesetting and proofreading procedure

Display of the result of downloads and visits, as well as the number of cited articles

Maximum dissemination of your research work

Submit your manuscript at: http://papersubmission.scirp.org/ 